A drift was started at this point and it was found that the richer channel continued to the east, gradually widening until it occupied the entire width of the shoot. This higher grade of ore carried more lead and silver than the adjoining low grade bodies, but contained the same amount of zinc.

Later, a large body of zinc ore, carrying from 30 to 40 per cent. of that metal, was found to the north of the main shoot, as shown on the sketch.

The fact that the richer sulphide core of the main shoot contained the same amount of zinc per ton throughout, as the adjoining low-grade portions and the existence of the body of clean zinc ore, seem to demonstrate that both phenomena were the result of secondary rearrangement.

Both instances illustrate that the values leached from orebodies by surface waters, will be found redeposited below and that, sometimes, it is wise to prospect for lost values outside of the main channel.

A third instance is found in the same district, but in a different ore-shoot.

Here the rocks had been eroded down to the ore-bodies in certain places. The ores were oxidized thoroughly. In one particular locality the ore-body had been eroded entirely, but here the loose, overlying wash was plastered with silver chlorides for a distance of Io feet above the rock in place. Several hundred tons of this loose rock, containing from 40 to 60 ounces of silver per ton, were shipped from this vicinity. This occurred at a depth of i 50 feet below the surface.

Denver Colorado.

MAX BOEHMER.

\title{
THE ORE DEPOSITS OF COPPEROPOLIS, CALIFORNIA.
}

DISCUSSION OF PAPER BY JOHN A. REID.

Sir: In the issue of Economic Geology for December, I907, Mr. H. W. Turner has contributed a discussion on my paper dealing with the Copperopolis ore deposits. In this discussion he appears indirectly to accuse me of having slighted the results 
of his own work in the Sierra Nevada. I wish to state that nothing was further from my thoughts, and I regret exceedingly to have laid myself open to such interpretation. I fully appreciate the great value of the work of both Mr. Turner and Mr. Lindgren, and I am very sorry that their labors in the Sierra have ceased. I noted the fact that in the papers referred to. hornblendite had not been given an individual place as a distinct species. This I did as I wished to emphasize the fact that I regard the Copperopolis rocks as originally amphibolitic and worthy of recognition as such. I have been able thus far to: detect no pyroxene, although further search may reveal this mineral. The porphyritic facies of the hornblendite shows large idiomorphic hornblendes, in a finer-grained matrix of the. same constituent with a little basic feldspar. There is no suggestion of derivation from pyroxene. At the same time I would class the hornblende rock with the family of the pyroxenites because in the Sierra Nevada the latter represent the prevailing mode of crystallization of the various similar ultrabasic intrusives. I have come to look upon the hornblendebearing rocks as having crystallized from magmas containing more water than those from which the pyroxenic rocks have resulted. I expect to be able to substantiate this belief in the future, particularly as the question bears distinctly upon the formation of ore deposits.

Mr. Turner's criticism of my ascribing the copper ore to the hornblendite is apparently a just one. It is obviously unscientific to connect the ore genetically with the upper portion of the basic intrusive, as the latter is in small volume. This brings: into the discussion a new line of inquiry, and a brief consideration of the recent paper of Mr. Spurr, "A Theory of Oredeposition." It has been forced upon my attention for some time that we cannot connect in many instances certain ore deposits with definite masses of igneous rocks, even though we may be sure from all the evidence that some genetic relationship holds. At Copperopolis the fresh hornblendite is copper-bearing, but the ore certainly did not come from the intrusive rock exposed in the mines. It must have come from the basic 
magmas below, the product of a deep differentiation. I think I used the phrase genetically connected with, in writing of this matter in my paper. Such a phrase is sufficiently elastic to cover our expanding knowledge of ore deposits. I believe that it ill befits the youngest members of the profession to put forth new theories; that work should be left to the older men. I agree with Mr. Spurr in part; in part I do not. I have seen comparatively too many instances of ore differentiation from the upper portions of intrusive magmas to allow me to adopt the idea of a predominant differentiation at great depth. I believe that the structural conditions, or better, the conditions of crustal stress at times of igneous intrusions play a great part in magmatic differentiation of ores and must be considered in a working theory of ore deposition. At Copperopolis the copper ore, and hornblendite illustrate deep differentiation; the granodiorite, with its original pyrite, is an example of differentiation in the upper portions of igneous intrusions. Both are true conditions, and we should not push either one too far.

In closing I can state that the paper on Copperopolis I hope to make but the beginning of further and more detailed studies of the copper belt. There is much to be done, for the field is almost untouched.

Truunfo, Baja California, Mexico, JoHN A. REID.

April 7, 1908. 